\title{
Pengaruh Pandemi Covid-19 Terhadap Jumlah Sampah di Tempat Pemrosesan Akhir Regional Kota Payakumbuh
}

\author{
Yenni Ruslinda $^{1^{*}}$, Indah Kurnia Asyura ${ }^{2}$, Rizki Aziz $^{3}$ \\ 1,2,3 Jurusan Teknik Lingkungan, Universitas Andalas, Padang \\ *Koresponden email: yenni@eng.unand.ac.id
}

Diterima: 23 September 2021

Disetujui: 30 Oktober 2021

\begin{abstract}
Restrictions on community activities during the Covid-19 pandemic have an impact on the amount of waste a city produces. This study aims to analyze the amount of incoming waste at the Payakumbuh Regional Final Processing Site (TPA) before and during the Covid-19 pandemic, analyze the impact of the pandemic on waste sources and provide recommendations for waste management during the pandemic. Data on the amount of waste entering the TPA was obtained from measurements of waste at the weighbridge before the pandemic (February - March 2020) and during the pandemic (April - May 2020). The analysis of the impact of the pandemic on the source of the waste is based on the results of interviews with truck drivers and analysis of truck routes. The results showed a decrease in the amount of waste transported to the landfill by $11.15 \%$ during the Covid-19 pandemic. The average amount of waste before the pandemic was 237.36 tons/day, while during the pandemic is 210.90 tons/day. The decrease in the amount of waste is due to restrictions on community activities outside the home with the implementation of the Large-Scale Social Restriction (PSBB) policy. The implementation of PSBB policy during the pandemic caused a decrease in the amount of waste from institutional, commercial and city service facilities by $29.48-50 \%$ and an increase in domestic sources by $21.22 \%$.
\end{abstract}

Keywords: Amount of waste, composition, covid-19 pandemic, source of waste, landfill

\begin{abstract}
Abstrak
Pembatasan aktivitas masyarakat saat pandemi Covid-19 berdampak terhadap jumlah sampah yang dihasilkan suatu kota. Penelitian ini bertujuan untuk menganalisis jumlah sampah masuk di Tempat Pemrosesan Akhir (TPA) sampah Regional Kota Payakumbuh sebelum dan saat pandemi Covid-19, menganalisis pengaruh pandemi terhadap sumber sampah dan memberikan rekomendasi pengelolaan sampah saat pandemi. Data jumlah sampah masuk ke TPA diperoleh dari pengukuran sampah di jembatan timbang sebelum pandemi (Bulan Februari - Maret 2020) dan saat pandemi (Bulan April - Mei 2020). Analisis pengaruh pandemi terhadap sumber sampah didasarkan pada hasil wawancara dengan sopir truk dan analisis rute truk. Hasil penelitian menunjukkan penurunan jumlah sampah yang masuk ke TPA saat pandemi sebesar $11,15 \%$. Jumlah sampah rata-rata sebelum pandemi sebesar 237,36 ton/hari, sedangkan saat pandemi menjadi 210,90 ton/hari. Penurunan jumlah sampah dikarenakan adanya pembatasan aktivitas masyarakat di luar rumah akibat pemberlakuan Pembatasan Sosial Berskala Besar (PSBB). Pemberlakukan PSBB saat pandemi menyebabkan penurunan jumlah sampah dari sumber institusi, komersil dan fasilitas pelayanan kota sebesar 29,48-50\% serta peningkatan jumlah sampah pada sumber domestik sebesar $21,22 \%$. Rekomendasi untuk masyarakat dalam pengelolaan sampah saat pandemi adalah pemilahan sampah, pengomposan sampah, daur ulang sampah, reduksi sampah dan penanganan sampah medis rumah tangga, serta untuk pemerintah melakukan sosialisasi, pelatihan dan kerjasama dengan sektor informal.
\end{abstract}

Kata Kunci: Jumlah sampah, komposisi, pandemi covid-19, sumber sampah, tempat pemrosesan akhir

\section{Pendahuluan}

Berdasarkan data WHO hingga 1 Maret 2020 sudah terdapat 65 negara yang terjangkit penyakit Coronavirus disease 2019 (Covid-19) yang diakibatkan oleh virus baru yaitu Corona Virus jenis SARSCoV-2, termasuk Indonesia. Infeksi Covid-19 berkembang sangat cepat, yang menimbulkan sesak nafas hingga gangguan gagal organ. Kondisi darurat ini terutama terjadi pada pasien dengan masalah kesehatan sebelumnya [1]. Salah satu upaya yang dilakukan untuk pencegahan penyebaran Covid-19 di Indonesia yaitu karantina wilayah dengan penerapan Pembatasan Sosial Berskala Besar (PSBB). PSBB adalah pembatasan kegiatan tertentu penduduk dalam suatu wilayah yang diduga terinfeksi penyakit dan/atau terkontaminasi sedemikian rupa untuk mencegah kemungkinan penyebaran penyakit atau kontaminasi. PSBB yang dimaksud meliputi peliburan sekolah dan tempat kerja, pembatasan kegiatan keagamaan, dan 
pembatasan kegiatan di tempat atau fasilitas umum [2]. Di Provinsi Sumatera Barat, PSBB diberlakukan sejak 22 April 2020 yang tertuang dalam Peraturan Gubernur Sumbar Nomor 20 Tahun 2020 tentang Pedoman Pembatasan Sosial Berskala Besar Dalam Penanganan Corona Virus Disease 2019 (Covid-19) di Provinsi Sumatera Barat [3].

Adanya perubahan aktivitas tersebut, diperkirakan berdampak terhadap jumlah sampah yang dihasilkan dari suatu kota. Dinas Lingkungan Hidup dan Kebersihan Kota Kabupaten Kepulauan Seribu mencatat jumlah sampah mengalami penurunan sebesar 53,74 \%. Jumlah sampah sebelum pandemi sebesar 777,82 ton/ hari dan saat pandemi menurun menjadi 359,85 ton/hari [4]. Sementara itu, berdasarkan data Dinas Lingkungan Hidup Kota Padang, sebelum pandemi produksi sampah Kota Padang adalah 500 - 600 ton/hari, sedangkan saat pandemi berlangsung menurun menjadi 200 - 400 ton/hari [5].

Tahap akhir dari pengelolaan sampah adalah pemrosesan akhir sampah yang dilakukan di Tempat Pemrosesan Akhir (TPA). TPA regional adalah TPA yang memiliki konsep tempat pemrosesan akhir sampah dari dua kota atau lebih pada lintas batas administrasi kota atau bahkan lintas provinsi [6]. Salah satu TPA Regional yang ada di Provinsi Sumatera Barat adalah TPA Sampah Regional Payakumbuh yang terletak di Taratak Kelurahan Kapalo Koto Kecamatan Payakumbuh Selatan. TPA Sampah Regional Payakumbuh hingga saaat ini melayani empat daerah layanan yaitu Kota Payakumbuh, Kabupaten 50 Kota, Kota Bukittinggi, dan Kabupaten Agam [7].

Pada saat pandemi, ke-empat daerah layanan TPA Regional Kota Payakumbuh ikut menerapkan kebijakan PSBB dalam pemutusan rantai penyebaran Covid-19, sehingga aktivitas masyarakat banyak dilakukan di rumah tangga. Aktivitas pada kegiatan komersil dan institusi relatif mengalami penurunan. Hal ini diduga berdampak terhadap jumlah sampah yang dihasilkan dari masing-masing daerah. Tujuan dari penelitian ini adalah menganalisis pengaruh pandemi Covid-19 terhadap jumlah sampah masuk ke TPA Regional Kota Payakumbuh dengan membandingkan jumlah sampah yang masuk sebelum dan saat pandemi serta menganalisis pengaruh pandemi Covid-19 pada masing-masing sumber sampah. Analisis jumlah sampah yang masuk didasarkan pada data hasil pengukuran dengan jembatan timbang di TPA, sedangkan analisis sumber sampah didasarkan pada rute truk dan hasil wawancara dengan sopir truk terkait jumlah sampah yang diangkut masing-masing truk sebelum dan saat pandemi Covid-19. Dari penelitian ini diharapkan dapat diperoleh kajian pengaruh pandemi Covid-19 terhadap jumlah sampah yang masuk ke TPA dan terhadap sumber sampah dari masing-masing daerah layanan serta rekomendasi pengelolaanya.

\section{Metode Penelitian}

Tahapan penelitian ini terdiri dari pengumpulan data primer dan sekunder serta pengolahan dan analisis data. Pengumpulan data primer dilakukan dengan wawancara terhadap sopir truk TPA Regional Kota Payakumbuh yang mewakili masing-masing daerah pelayanan dan wawancara dengan pegawai Dinas Lingkungan Hidup masing-masing kota/kabupaten daerah layanan. Wawancara dengan sopir truk dimaksudkan untuk menanyakan perubahan yang terjadi terhadap jumlah sampah dari masing-masing sumber sampah daerah layanannya. Data ini diperlukan untuk menganalisis pengaruh pandemi terhadap masing-masing sumber sampah. Wawancara dengan pegawai Dinas Lingkungan Hidup masing-masing kota/kabupaten daerah layanan dibutuhkan untuk mendapatkan data pengelolaan sampah sebelum dan saat pandemi berlangsung. Jumlah sopir truk yang diwawancara dihitung berdasarkan rumus SNI 19-3964-1994 tentang Metode Pengambilan dan Pengukuran Contoh Timbulan dan Komposisi Sampah Perkotaan, dengan persamaan sebagai berikut [8]:

$$
S=C d \sqrt{T} S
$$

dimana:

$\mathrm{S} \quad=$ Jumlah sampel

$\mathrm{Cd}=$ Koefisien non perumahan $=1$

Ts = Jumlah populasi

Dengan jumlah truk (Ts) sebanyak 42 truk dan Cd untuk kota kecil sebesar 1, hingga didapatkan jumlah sopir truk yang diwawancara berjumlah 7 orang. Jumlah ini telah memenuhi syarat dengan tingkat kepercayaan $95 \% .7$ orang sampel sopir truk yang diwawancara terdiri dari 3 orang yang mewakili daerah layanan Kota Bukittinggi, 2 orang mewakili daerah layanan Kota Payakumbuh, dan masing-masing 1 orang mewakili daerah layanan Kabupaten 50 Kota dan Kabupaten Agam.

Pengumpulan data sekunder dalam penelitian ini adalah pengumpulan data jumlah sampah yang masuk ke TPA Regional Payakumbuh dari masing-masing daerah layanan. Data jumlah sampah yang masuk ke TPA pada saat sebelum pandemi Covid-19 diwakili data Februari dan Maret 2020 dan pada saat 
terjadi pandemi Covid-19 atau diberlakukan PSBB di Sumatera Barat diwakili data Bulan April dan Mei 2020. Jumlah sampah yang masuk ke TPA diambil dari pengukuran berat sampah menggunakan jembatan timbang. Selain itu juga dibutuhkan data rute masing-masing truk yang masuk ke TPA untuk menentukan sumber sampah dari masing-masing layanan truk. Data ini diperoleh dari Dinas Lingkungan Hidup masingmasing kota/kabupaten layanan.

Selanjutnya dilakukan pengolahan dan analisis data meliputi analisis jumlah sampah yang masuk TPA sebelum dan saat pandemi Covid-19 di TPA Regional Kota Payakumbuh serta analisis pengaruh pandemi terhadap masing-masing sumber sampah. Analisis jumlah sampah yang masuk ke TPA Regional Kota Payakumbuh dilakukan dengan membandingkan data jumlah rata-rata sampah yang masuk sebelum pandemi Covid-19 dengan data saat pandemi serta data saat PSBB diberlakukan. Analisis juga dilakukan dengan membandingkan data TPA Regional Kota Payakumbuh dengan kota-kota lainnya baik di Indonesia mapun di dunia pada saat pandemi Covid-19.

\section{Analisis Data}

Analisis pengaruh pandemi Covid-19 terhadap masing-masing sumber sumber sampah dilakukan dengan langkah sebagai berikut:

- menentukan persentase masing-masing sumber sampah dari layanan truk yang didasarkan pada data rute truk

- menentukan jumlah sampah yang diangkut ke TPA dari masing-masing sampel truk sebelum dan saat pandemi berlangsung, yang diperoleh dari pencatatan berat sampah dengan jembatan timbang

- menentukan kenaikan dan penurunan jumlah sampah dari masing-masing sumber layanan truk sampah pada saat pandemi berlangsung, yang diperoleh dari wawancara dengan sopir truk sampah

- menghitung jumlah sampah dari masing masing sumber layanan truk sampah pada saat sebelum dan saat pandemi

- menghitung persentase kenaikan atau penurunan jumlah sampah saat pandemi dari masing-masing sumber sampah.

\section{Hasil dan Pembahasan}

\section{Jumlah Sampah Masuk ke TPA Regional Kota Payakumbuh}

TPA Regional Kota Payakumbuh menerima sampah dari empat daerah layanan yaitu Kota Payakumbuh, Kota Bukittinggi, Kabupaten 50 Kota, dan Kabupaten Agam. Berdasarkan hasil perhitungan di dapatkan jumlah sampah masuk dari Kota Payakumbuh mengalami penurunan sebesar 11,52\% saat pandemi Covid-19. Jumlah rata-rata sampah yang masuk sebelum pandemi Covid-19 dari Kota Payakumbuh sebesar 82,526 ton/hari sedangkan saat pandemi Covid-19 berlangsung sebesar 73,021 ton/hari. Gambar 1 menampilkan perbandingan sampah yang masuk ke TPA sebelum dan saat pandemi Covid-19 dari Kota Payakumbuh.

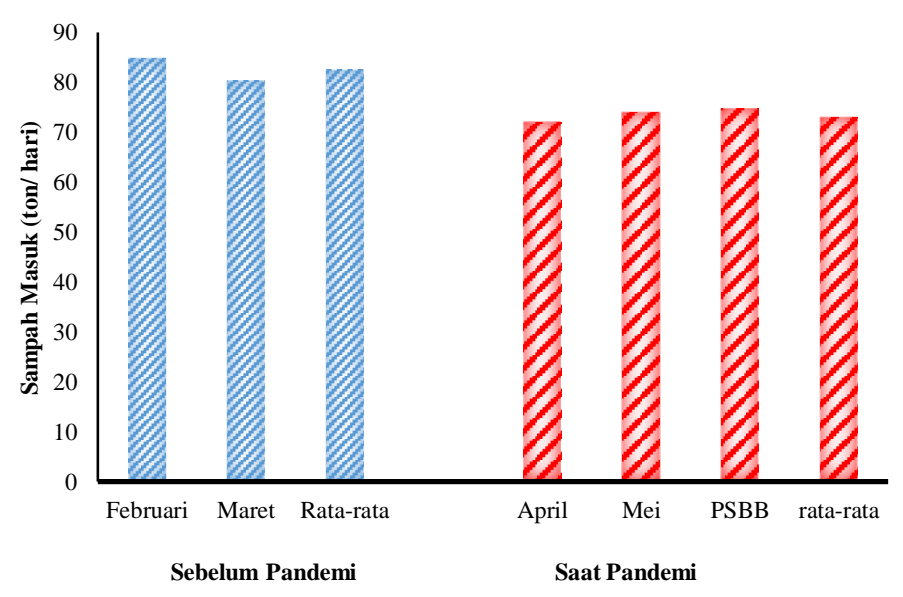

Gambar 1. Perbandingan jumlah sampah masuk sebelum dan saat pandemi Covid-19 dari Kota Payakumbuh Sumber: TPA Regional Kota Payakumbuh (2020)

Perbandingan rata-rata jumlah sampah yang masuk ke TPA sebelum dan saat pandemi berlangsung dari daerah layanan Kota Bukitinggi dapat dilihat pada Gambar 2. Jumlah rata-rata sampah yang masuk ke TPA Regional Kota Payakumbuh dari daerah layanan Kota Bukittinggi sebelum pandemi sebesar 114,731 ton/hari. Namun pada saat pandemi Covid-19, terjadi penurunan jumlah sampah yang masuk ke 
TPA sebesar 10,23\%. Jumlah rata-rata sampah yang masuk ke TPA dari daerah layanan Kota Bukittinggi pada saat pandemi Covid -19 menurun menjadi 102,992 ton/hari.

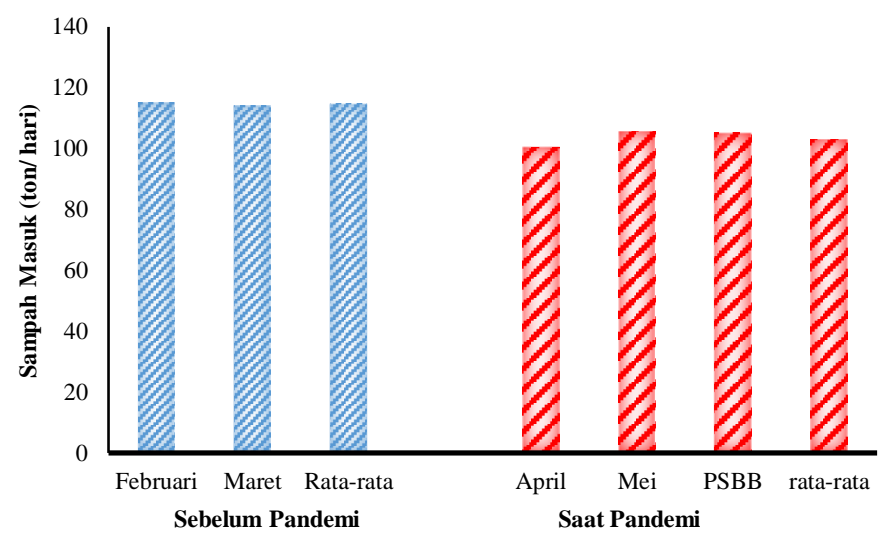

Gambar 2. Perbandingan jumlah sampah masuk sebelum dan saat pandemi Covid-19 dari Kota Bukittinggi Sumber: TPA Regional Kota Payakumbuh (2020)

Jumlah sampah rata-rata yang masuk dari Kabupaten 50 Kota ke TPA Regional Kota Payakumbuh pada saat pandemi Covid-19 berlangsung mengalami penurunan sebesar 19,25\%. Berdasarkan hasil perhitungan, didapatkan jumlah rata-rata sampah yang masuk ke TPA Regional Kota Payakumbuh dari daerah layanan Kabupaten 50 Kota sebelum pandemi sebesar 15,066 ton/hari, sedangkan pada saat pandemi Covid-19 menurun menjadi 12,166 ton/hari. Perbandingan ini dapat dilihat pada Gambar 3.

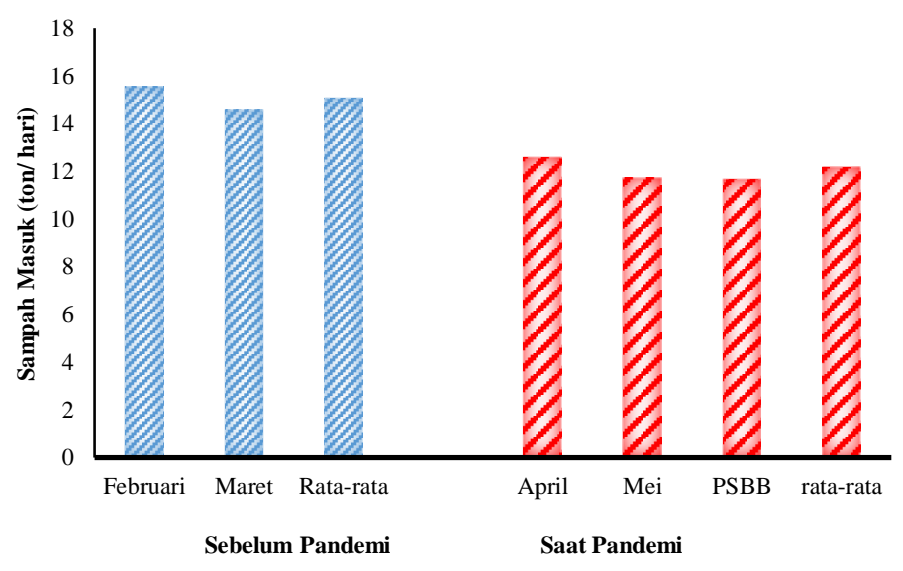

Gambar 3. Perbandingan jumlah sampah masuk sebelum dan saat pandemi covid-19 dari Kabupaten 50 kota Sumber: TPA Regional Kota Payakumbuh (2020)

Saat pandemi Covid-19 berlangsung, terjadi penurunan jumlah sampah yang diangkut ke TPA Regional Kota Payakumbuh dari layanan Kabupaten Agam sebesar 9,26\%. Jumlah rata-rata sampah masuk dari daerah layanan Kabupaten Agam sebelum pandemi Covid-19 sebesar 25,036 ton/hari, sedangkan pada saat pandemi berlangsung sebesar 22,717 ton/hari. Gambar 4 menampilkan perbandingan jumlah sampah yang masuk ke TPA dari daerah layanan Kabupeten Agam.

Hasil rekapitulasi rata-rata jumlah sampah yang masuk ke TPA Regional Kota Payakumbuh dari masing-masing daerah layanan ditampilkan pada Tabel 1. Dari Tabel 1 terlihat jumlah sampah yang paling banyak masuk ke TPA Regional Kota Payakumbuh berasal dari daerah layanan Kota Bukittinggi baik sebelum dan saat pandemi terjadi. Hampir separuh dari sampah di TPA berasal dari Kota Bukittinggi. Selanjutnya dari daerah layanan Kota Payakumbuh menyumbang sepertiga dari jumlah sampah yang ada di TPA. Jumlah sampah paling sedikit berasal dari daerah layanan Kabupaten 50 Kota. 


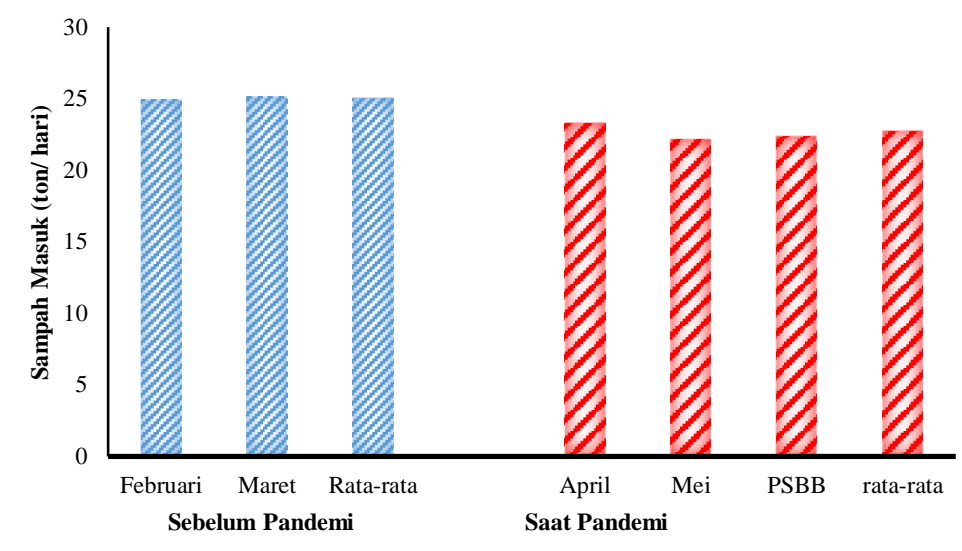

Gambar 4. Perbandingan jumlah sampah masuk sebelum dan saat pandemi Covid-19 dari Kabupaten Agam Sumber: TPA Regional Kota Payakumbuh (2020)

Tabel 1. Rekapitulasi jumlah sampah masuk ke TPA Regional Kota Payakumbuh

\begin{tabular}{lccc}
\hline \multirow{2}{*}{ Daerah Layanan } & \multicolumn{2}{c}{ Jumlah Sampah yang Masuk TPA (ton/ hari) } & \multirow{2}{*}{ Perubahan } \\
\cline { 2 - 3 } & Sebelum Pandemi & Saat Pandemi & \\
\hline Kota Payakumbuh & 82,526 & 73,021 & Penurunan $11,52 \%$ \\
Kota Bukittinggi & 114,731 & 102,992 & Penurunan $10,23 \%$ \\
Kabupaten 50 Kota & 15,066 & 12,166 & Penurunan 19,25\% \\
Kabupaten Agam & 25,036 & 22,717 & Penurunan 9,26\% \\
Total & 237,359 & 210,896 & Penurunan $11,15 \%$ \\
\hline
\end{tabular}

Sumber: Hasil perhitungan (2020)

Berdasarkan data-data di atas didapatkan jumlah sampah yang masuk ke TPA Regional Kota Payakumbuh dari empat daerah layanan sebesar 237,359 ton/hari pada saat sebelum pandemi. Jumlah ini mengalami penurunan menjadi 210,896 ton/hari pada saat pandemi Covid-19 berlangsung. Persentase penurunan jumlah sampah yang masuk ke TPA Regional Kota Payakumbuh saat pandemi sebesar 11,15\%. Gambar 5 menampilkan perbandingan rata-rata jumlah sampah masuk ke TPA Regional Kota Payakumbuh sebelum dan saat pandemi Covid-19 berlangsung. Dari Gambar 5 juga terlihat penurunan jumlah sampah yang masuk ke TPA Regional Kota Payakumbuh saat PSBB diberlakukan, yaitu menjadi 213,975 ton/ hari.

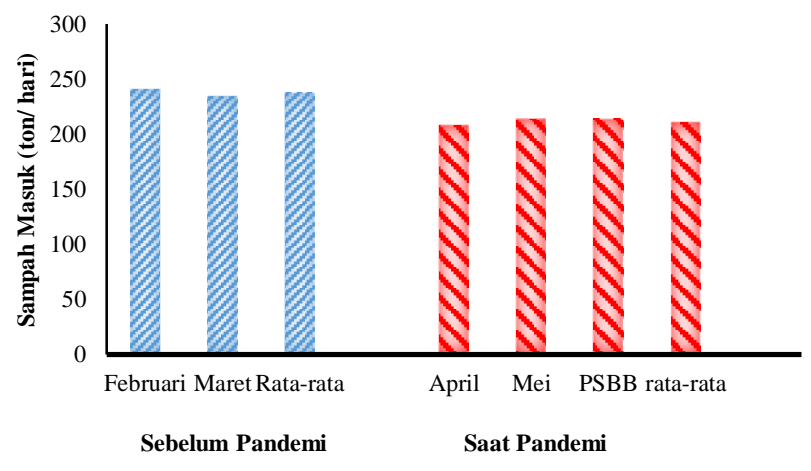

Gambar 5. Perbandingan sampah masuk sebelum dan saat pandemi Covid-19 di TPA Regional Kota Payakumbuh Sumber: Hasil perhitungan (2020)

Gambar 6 menampilkan fluktuasi harian jumlah sampah yang masuk ke TPA Regional Kota Payakumbuh sebelum dan saat pandemi Covid-19. Sebelum pandemi Covid-19, jumlah sampah yang masuk perharinya ke TPA terlihat lebih berfluktuasi. Jumlah sampah pada hari kerja lebih tinggi dibandingkan pada akhir minggu atau pada hari libur. Jumlah sampah pada saat hari kerja berkisar antara 200 - 260 ton/hari, sedangkan pada akhir minggu berkisar antara 185 - 230 ton/hari. Pada akhir minggu aktivitas perkantoran dan pendidikan umumnya libur, sehingga mengurangi jumlah sampah yang diangkut 
ke TPA. Namun pada saat pandemi Covid-19 berlangsung, jumlah sampah yang masuk ke TPA Regional Kota Payakumbuh pada hari kerja dan hari libur relatif sama. Hal ini dikarenakan aktivitas masyarakat selama pandemi relatif sama setiap harinya. Aktivitas perkantoran dan pendidikan banyak dilakukan dari rumah. Sementara selama PSBB aktivitas di sarana komersil juga dibatasi.

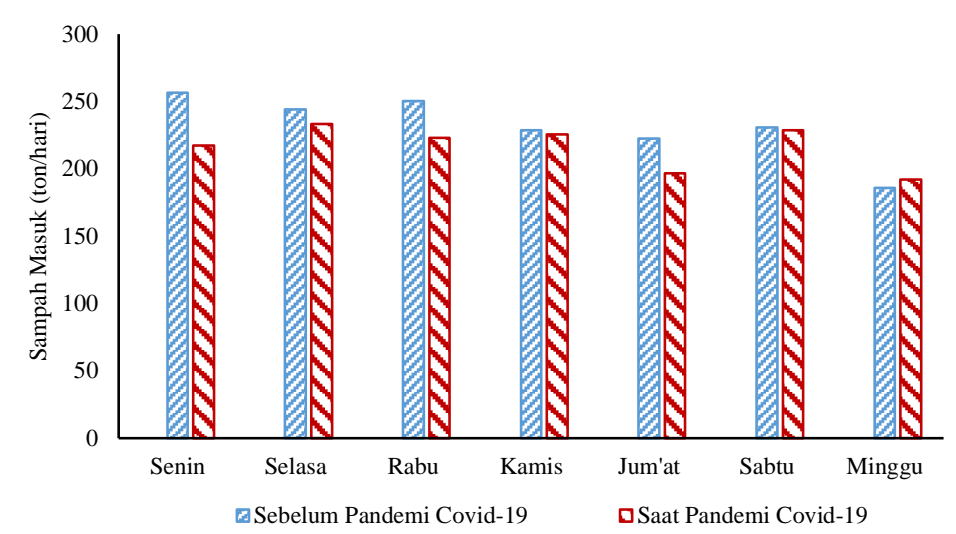

Gambar 6. Fluktuasi harian jumlah sampah masuk ke TPA Regional Kota Payakumbuh Sumber: TPA Regional Kota Payakumbuh (2020)

Penurunan jumlah sampah saat pandemi Covid-19 berlangsung tidak hanya terjadi di TPA Regional Payakumbuh, namun juga di kota-kota lain di Indonesia dan di dunia. Tabel 2 menampilkan perbandingan jumlah sampah sebelum dan saat pandemi Covid-19 di beberapa kota. Menurut penelitian yang dilakukan oleh ref. [9] pada kawasan Summarecon Serpong (Indonesia) terjadi penurunan sampah sebesar 55\%. Jumlah sampah sebelum pandemi pada kawasan ini sebesar $89,9 \mathrm{~m}^{3} /$ hari dan pada saat pandemi menjadi 49,6 $\mathrm{m}^{3} /$ hari. Kawasan Summarecon ini terletak tidak jauh dari Kota Jakarta dan merupakan kota satelit yang berada di Kawasan Gading Serpong, Kabupaten Tangerang, sehingga secara tidak langsung kawasan ini terdampak Covid-19 [9]. Penurunan jumlah sampah juga terjadi di wilayah Jakarta Timur dengan penurunan sebesar $17,35 \%$ [3].

Tabel 2. Perbandingan jumlah sampah sebelum dan saat pandemi Covid-19 di beberapa kota

\begin{tabular}{|c|c|c|c|c|}
\hline \multirow[b]{2}{*}{ Kawasan } & \multicolumn{2}{|c|}{ Jumlah Sampah } & \multirow[b]{2}{*}{ Perubahan } & \multirow[b]{2}{*}{ Sumber } \\
\hline & $\begin{array}{l}\text { Sebelum } \\
\text { Pandemi }\end{array}$ & $\begin{array}{c}\text { Saat } \\
\text { Pandemi }\end{array}$ & & \\
\hline $\begin{array}{l}\text { Kawasan Summarecon } \\
\text { Serpong (Indonesia) }\end{array}$ & $89,9 \mathrm{~m}^{3} /$ hari & $49,6 \mathrm{~m}^{3} /$ hari & Penurunan $55 \%$ & [9] \\
\hline Jakarta Timur & $1.958,2$ ton/ hari & $\begin{array}{c}1.618,52 \text { ton/ } \\
\text { hari }\end{array}$ & Penuruna $17,35 \%$ & [3] \\
\hline Bandung & 1.347 ton/hari & 1.277 ton/hari & Penurunan $5,2 \%$ & {$[10]$} \\
\hline Cianjur & 212,64 ton/hari & 174,79 ton/hari & Penurunan $17,8 \%$ & [11] \\
\hline Kepulauan Seribu & $\begin{array}{c}777,822 \text { ton/ } \\
\text { hari }\end{array}$ & 359,85 ton/ hari & Penurunan $53,74 \%$ & {$[12]$} \\
\hline Khenifra (Maroko) & $\begin{array}{c}4.881,80 \\
\text { ton/hari }\end{array}$ & $\begin{array}{c}4.605,94 \\
\text { ton/hari }\end{array}$ & Penurunan $5,57 \%$ & [13] \\
\hline Tighassaline (Maroko) & 265,7 ton/hari & 250,9 ton/hari & Penurunan $5,65 \%$ & [13] \\
\hline $\begin{array}{l}\text { TPA Regional Kota } \\
\text { Payakumbuh }\end{array}$ & $\begin{array}{l}237,359 \\
\text { ton/hari }\end{array}$ & $\begin{array}{l}210,896 \\
\text { ton/hari }\end{array}$ & Penurunan $11,15 \%$ & \\
\hline
\end{tabular}
Sumber: Pengolahan data (2020)

Tidak hanya di wilayah Jakarta yang merupakan kota metropolitan, di kota-kota kecil seperti Kota Cianjur dan Kepulauan Seribu juga mengalami penurunan jumlah sampah masing-masing sebesar 17,8\% dan 53,74\%. Sementara kota-kota kecil di Sumatera Barat seperti Kota Bukittinggi, Kota Payakumbuh, Kabupaten Agam dan Kabupaten 50 Kota juga mengalami penurunan jumlah sampah sebesar 9 - 19\%, seperti yang diperoleh dari penelitian ini yang menganalisis jumlah sampah yang masuk ke TPA Regional Kota Payakumbuh. Ke-empat kota tersebut merupakan daerah layanan TPA Regional Kota Payakumbuh.

Penurunan jumlah sampah saat pandemi juga terjadi pada kategori kota besar seperti Kota Bandung yang mengalami penurunan jumlah sampah sebesar 5,2\% [10]. Nilai ini hampir sama dengan penurunan sampah di Kota Khenifra dan Kota Tighassaline di negara Maroko dengan penurunan jumlah sampah 
masing-masing sebesar 5,57\% dan 5,65\% [13]. Penelitian di Negara Maroko juga dilakukan pada Kota Marakesh pada tiga daerah pengukuran A, B, dan C. Hasil penelitian juga menunjukkan terjadinya penurunan sampah dari 1,23 menjadi 0,84 kg per kapita per hari untuk daerah $\mathrm{A}$, dari 0,92 hingga $0,60 \mathrm{~kg}$ per kapita per hari untuk daerah $\mathrm{B}$, dan dari 0,88 menjadi $0,73 \mathrm{~kg}$ per kapita per hari untuk daerah C [14]. Penurunan sampah selama pandemi Covid-19 terjadi dikarenakan pembatasan aktivitas masyarakat seperti PSBB di Indonesia dan pemberlakuan lockdown di beberapa negara lain, serta adanya krisis ekonomi yang terjadi saat pandemi Covid-19 berlangsung sehingga menyebabkan daya konsumsi masyarakat ikut menurun.

\section{Pengaruh Pandemi Covid-19 terhadap Sumber Sampah}

Tabel 3 menampilkan perubahan jumlah sampah di masing-masing sumber. Dari jalur rute truk sampah (kolom a) yang diperoleh dari DLH masing-masing kota dianalisis sumber sampah dari masingmasing truk (kolom b). Selanjutnya data perubahan jumlah sampah yang terjadi selama masa pandemi diperoleh melalui wawancara dengan sampel sopir truk (kolom c). Hasil wawancara menunjukkan adanya penurunan jumlah sampah dari sumber non domestik seperti sumber komersil, institusi, dan pelayanan kota, sedangkan peningkatan jumlah sampah sampah terjadi pada sumber domestik.

Selanjutnya dilakukan perhitungan jumlah sampah yang masuk ke TPA Regional Kota Payakumbuh sebelum dan saat pandemi untuk masing-masing sumber sampah, seperti ditampilkan pada Tabel 4. Perhitungan ini didasari dari hasil wawancara dengan sopir truk dan jumlah sampah yang diangkut ke TPA masing-masing truk sebelum dan saat pandemi. Data ini ini diperoleh dari pengolahan data berat sampah dengan pengukuran jembatan timbang di TPA (kolom d). Dari data kolom d ini, dihitung persentase perubahan yang terjadi selama masa pandemi Covid-19 untuk masing-masing sumber sampah (kolom e).

Berdasarkan hasil wawancara pada tujuh sopir truk, didapatkan hasil perubahan jumlah sampah di masing-masing sumber pada setiap daerah layanan. Kota Bukittinggi mengalami penurunan sampah dari setiap sumber yaitu pada sumber domestik sebesar 5,3\%, komersil 11,82\%, institusi $22,22 \%$, dan pelayanan perkotaan 2,6\%. Kabupaten 50 Kota mengalami kenaikan sampah di sumber domestik sebesar 2,5\% serta penurunan sampah pada sumber komersil sebesar $25 \%$ dan pelayanan perkotaan $66,67 \%$.

Tabel 3. Perubahan sampah berdasarkan sumber sampah

\begin{tabular}{|c|c|c|c|c|c|c|c|}
\hline \multirow[b]{2}{*}{$\begin{array}{l}\text { No. } \\
\text { Truk }\end{array}$} & \multirow[b]{2}{*}{$\begin{array}{l}\text { Daerah } \\
\text { Pelayanan }\end{array}$} & \multirow[b]{2}{*}{$\begin{array}{l}\text { Rute Truk } \\
\text { (a) }\end{array}$} & \multirow[b]{2}{*}{$\begin{array}{l}\text { Sumber } \\
\text { (b) }\end{array}$} & \multicolumn{4}{|c|}{ Perubahan Sampah (c) } \\
\hline & & & & Domestik & Komersil & Institusi & $\begin{array}{l}\text { Fasilitas } \\
\text { Layanan } \\
\text { Kota }\end{array}$ \\
\hline 1 & $\begin{array}{l}\text { Kota } \\
\text { Bukittinggi } \\
\text { (BT) }\end{array}$ & $\begin{array}{l}\text { Kantor pos jirek, Jl. Veteran, } \\
\text { Jl. Dr. Abdul rivai, Panorama, } \\
\text { DPRD, Jl. Perintis } \\
\text { kemerdekaan, bypass, Tarok, } \\
\text { asrama polisi, Kodim, TPA }\end{array}$ & $\begin{array}{l}60 \% \text { domestik, } 25 \% \\
\text { institusi, dan } 15 \% \\
\text { fasilitas pelayanan } \\
\text { kota }\end{array}$ & $\begin{array}{l}\text { Meningkat } \\
1 / 4 \mathrm{x} \\
\text { sebelum } \\
\text { pandemi }\end{array}$ & & $\begin{array}{l}\text { Menurun } \\
2 / 3 x \\
\text { sebelum } \\
\text { pandemi }\end{array}$ & $\begin{array}{l}\text { penurunan } \\
\text { tidak } \\
\text { signifikan }\end{array}$ \\
\hline 2 & $\begin{array}{l}\text { Kota } \\
\text { Bukittinggi } \\
\text { (BT) }\end{array}$ & $\begin{array}{l}\text { Pasar Banto, BTC, J1. Pemuda, } \\
\text { KFC, smp. Raya, Hotel Denai, } \\
\text { Jl. Angku basa, TPA }\end{array}$ & $\begin{array}{l}40 \% \text { Domestik dan } \\
60 \% \text { komersil }\end{array}$ & & $\begin{array}{l}\text { Menurun } \\
1 / 4 \mathrm{x} \\
\text { sebelum } \\
\text { pandemi }\end{array}$ & & \\
\hline 3 & $\begin{array}{l}\text { Kota } \\
\text { Bukittinggi } \\
\text { (BT) }\end{array}$ & Terminal Aur Kuning, TPA & $100 \%$ komersil & & $\begin{array}{l}2 \text { ton/ } \\
\text { hari }\end{array}$ & & \\
\hline 4 & $\begin{array}{l}\text { Kabupaten } 50 \\
\text { Kota (Kab.50) }\end{array}$ & $\begin{array}{c}\text { Lubuak Bangku, Harau, Pasar } \\
\text { Sarilamak, sepanjang Jl. } \\
\text { Tanjung Pati, TPA }\end{array}$ & $\begin{array}{l}30 \% \text { Domestik, } 45 \% \\
\text { Komersil, dan } 25 \% \\
\text { fasilitas Layanan } \\
\text { Kota }\end{array}$ & $\begin{array}{l}\text { Peningkatan } \\
\text { tidak } \\
\text { signifikan }\end{array}$ & $\begin{array}{l}\text { Menurun } \\
1 / 4 \mathrm{x} \\
\text { sebelum } \\
\text { pandemi }\end{array}$ & & $\begin{array}{l}\text { Menurun } \\
\text { 2/3x sebelum } \\
\text { pandemi }\end{array}$ \\
\hline 5 & $\begin{array}{l}\text { Kota } \\
\text { Payakumbuh } \\
(\text { PYK) }\end{array}$ & $\begin{array}{c}\text { Koto nan gadang, depan } \\
\text { Apotek Sudirman, nurul fikri, } \\
\text { samping tivani houseware, } \\
\text { hotel mangkuto, TPA }\end{array}$ & $\begin{array}{l}60 \% \text { domestik dan } \\
40 \% \text { komersil }\end{array}$ & $\begin{array}{l}\text { Meningkat } \\
1 / 4 \mathrm{x} \\
\text { sebelum } \\
\text { pandemi }\end{array}$ & & & \\
\hline 6 & $\begin{array}{l}\text { Kota } \\
\text { Payakumbuh } \\
(\text { PYK) }\end{array}$ & $\begin{array}{l}\text { Pasar Payakumbuh blok barat } \\
\text { dan nunang, TPA }\end{array}$ & $\begin{array}{l}30 \% \text { domestik dan } \\
70 \% \text { komersil }\end{array}$ & & $\begin{array}{l}2 \text { ton/ } \\
\text { hari }\end{array}$ & & \\
\hline 7 & $\begin{array}{l}\text { Kabupaten } \\
\text { Agam (AG) }\end{array}$ & $\begin{array}{c}\text { Balingka, Nagari Guguak, } \\
\text { Pasar Baso, IPDN, Diklat, } \\
\text { SMA } 1 \text { Baso, SMA } 1 \text { Ampek } \\
\text { Angkek, Pasar Koto Baru, } \\
\text { Pasar Lasi, TPA }\end{array}$ & $\begin{array}{l}25 \% \text { domestik, } 50 \% \\
\text { komersil, dan } 25 \% \\
\text { institusi }\end{array}$ & & $\begin{array}{l}\text { Menurun } \\
1 / 4 \mathrm{x} \\
\text { sebelum } \\
\text { pandemi }\end{array}$ & $\begin{array}{l}\text { Menurun } \\
1 / 3 \\
\text { sebelum } \\
\text { pandemi }\end{array}$ & \\
\hline
\end{tabular}

Sumber: Hasil perhitungan (2020) 
Tabel 4. Perhitungan perubahan sampah berdasarkan sumber sampah

\begin{tabular}{|c|c|c|c|c|c|c|c|c|c|c|c|c|c|c|c|}
\hline \multirow{3}{*}{$\begin{array}{l}\text { No. } \\
\text { Truk }\end{array}$} & \multirow{3}{*}{$\begin{array}{c}\text { Daerah } \\
\text { Pelayanan }\end{array}$} & \multirow{2}{*}{\multicolumn{2}{|c|}{$\begin{array}{c}\text { Rata-rata } \\
\text { sampah } \\
\text { diangkut } \\
\text { (ton/hari) (d) }\end{array}$}} & \multicolumn{12}{|c|}{ Persentase Perubahan (e) } \\
\hline & & & & \multicolumn{3}{|c|}{ Domestik } & \multicolumn{3}{|c|}{ Komersil } & \multicolumn{3}{|c|}{ Institusi } & \multicolumn{3}{|c|}{$\begin{array}{c}\text { fasilitas pelayanan } \\
\text { kota }\end{array}$} \\
\hline & & SB & SA & SB & SA & $\%$ & SB & SA & $\%$ & SB & SA & $\%$ & SB & SA & $\%$ \\
\hline 1 & BKT & 8,04 & 5,4 & 4,82 & 3,62 & -25 & & & & 2,01 & 0,67 & $-66,67$ & $\begin{array}{c}1,2 \\
1\end{array}$ & 1,11 & $\begin{array}{c}- \\
7,79\end{array}$ \\
\hline 2 & BKT & 7,66 & 6,79 & 3,06 & 3,34 & $+9,11$ & 4,60 & 3,45 & -25 & & & & & & \\
\hline 3 & BKT & 8,03 & 7,19 & & & & 8,03 & 7,19 & $-10,46$ & & & & & & \\
\hline & Rata-rata & 7,91 & 6,46 & 2,63 & 2,32 & $-5,30$ & 4,21 & 3,55 & $-11,82$ & 0,67 & 0,22 & $-22,22$ & $\begin{array}{c}0,4 \\
0\end{array}$ & 0,37 & $-2,60$ \\
\hline 4 & 50 KOTA & 3,94 & 2,87 & 1,18 & 1,21 & $+2,53$ & 1,77 & 1,33 & -25 & & & & $\begin{array}{c}0,9 \\
9\end{array}$ & 0,33 & $-66,67$ \\
\hline & Rata-rata & 3,94 & 2,87 & 1,18 & 1,21 & $+2,53$ & 1,77 & 1,33 & -25 & & & & $\begin{array}{c}0,9 \\
9\end{array}$ & 0,33 & $-66,67$ \\
\hline 5 & PYK & 3,39 & 2,65 & 2,03 & 1,53 & -25 & 1,36 & 1,12 & $-17,07$ & & & & & & \\
\hline 6 & PYK & 3,84 & 3,06 & 1,15 & 2,37 & $+105,7$ & 2,69 & 0,69 & $-74,33$ & & & & & & \\
\hline & Rata-rata & 3,62 & 2,86 & 1,59 & 1,95 & $+40,35$ & 2,03 & 0,91 & $-45,70$ & & & & & & \\
\hline 7 & AG & 5,31 & 5 & 1,33 & 2,12 & $+59,98$ & 2,66 & 1,99 & -25 & 1,33 & 0,9 & $-33,33$ & & & \\
\hline & Rata-rata & 5,31 & 5 & 1,33 & 2,12 & $+59,98$ & 2,66 & 1,99 & -25 & 1,33 & 0,9 & $-33,33$ & & & \\
\hline \multicolumn{4}{|c|}{$\begin{array}{c}\text { Rata-rata Perubahan } \\
\text { Sampah Sebelum dan Saat } \\
\text { Pandemi Covid-19 }\end{array}$} & \multicolumn{3}{|c|}{$\begin{array}{c}\text { Kenaikan } \\
21,22 \%\end{array}$} & \multicolumn{3}{|c|}{$\begin{array}{c}\text { Penurunan } \\
29,48 \%\end{array}$} & \multicolumn{3}{|c|}{$\begin{array}{l}\text { Penurunan } \\
50 \%\end{array}$} & \multicolumn{3}{|c|}{$\begin{array}{c}\text { Penurunan } \\
37,23 \%\end{array}$} \\
\hline
\end{tabular}

Sumber: Hasil perhitungan (2020)

Perubahan timbulan sampah yang terjadi pada daerah layanan Kota Payakumbuh cukup besar yaitu peningkatan sebesar $40,35 \%$ pada sumber domestik, sementara pada sumber komersil mengalami penurunan sebesar 45,70\%. Kenaikan sampah domestik terbesar terjadi di Kabupaten Agam sebesar $59,98 \%$, namun mengalami penurunan sampah komersil sebesar 25\% dan sampah institusi sebesar 33,33\%. Dari data ini terlihat adanya kenaikan timbulan sampah dari sumber domestik dan penurunan sampah pada sumber komersial, institusi dan pelayanan perkotaan.

Persentase perubahan yang terjadi baik penurunan maupun kenaikan jumlah sampah dari masingmasing sumber dilakukan dengan merata-ratakan persentase dari ketujuh sampel yang dihitung. Dari pengolahan data ini didapatkan adanya penurunan sampah dari sumber sumber komersil, institusi dan fasiltas palayanan kota masing-masing sebesar 29,48\%, 50\%, dan 37,23\%. Penurunan sampah ini dipengaruhi oleh pembatasan aktivitas masyarakat selama pemberlakuan PSBB di Sumatera Barat. Namun pada sumber domestik terjadi kenaikan jumlah sebesar 21,22\% pada saat pandemi Covid-19. Hal ini dikarenakan aktivitas masyarakat yang telah dialihkan ke rumah, sehingga sampah lebih banyak di hasilkan dari sumber domestik. Gambar 6 menampilkan persentase perubahan sampah pada saat pandemi di masing-masing sumber sampah.

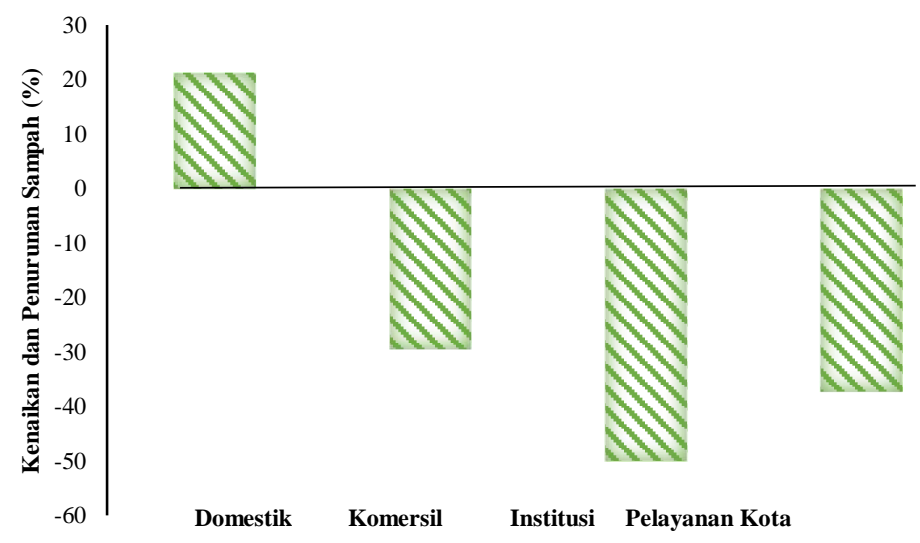

Gambar 6. Persentase perubahan jumlah sampah berdasarkan sumber saat pandemi Covid-19 Sumber: Hasil Perhitungan (2020) 
Berdasarkan penelitian Ruslinda, dkk di Kota Padang didapatkan timbulan sampah dari sumber domestik pada saat pandemi Covid-19 hampir dua kali dari timbulan sampah sebelum pandemi. Timbulan sampah sebelum pandemi sebesar $0,210 \mathrm{Kg} /$ orang/hari, sedangkan saat pandemi menjadi 0,410 $\mathrm{Kg} /$ orang/hari. Jenis sampah yang paling banyak dihasilkan adalah sampah makanan dan sampah plastik. Kenaikan sampah makanan dikarenakan kegiatan masak-memasak termasuk kegiatan yang banyak dilakukan di rumah tangga saat diberlakukan WFH/SFH [15].

Sampah plastik memiliki jumlah yang cukup tinggi saat pandemi berlangsung. Hal ini sesuai dengan penelitian yang dilakukan oleh Institusi Teknologi Surabaya (ITS) yang menyatakan sampah plastik di TPA Benowo, Surabaya, saat pandemi Covid-19 meningkat hingga 22,01\% dari 13,37\% pada Tahun 2017. Penelitian yang dilakukan oleh Lembaga Ilmu Pengetahuan Indonesia (LIPI) menyebutkan bahwa 96\% belanja online menggunakan bahan kemasan dari plastik. Selain itu LIPI juga melakukan penelitian di daerah Jabodetabek yang menunjukkan hasil sampah plastik dari jasa antar paket meningkat $62 \%$ dan dari jasa antar makanan siap saji meningkat 47\% [16]. Selain sampah sisa makanan dan plastik, sampah B3 medis berupa masker bekas, botol handsanitizer, dan sarung tangan bekas, serta Alat Pelindung Diri (APD) ikut meningkat selama pandemi Covid-19 berlangsung. Menurut Kementerian Lingkungan Hidup dan Kehutanan (KLHK) jumlah limbah B3 medis di Indonesia meningkat 30\% di saat pandemi. KLHK mencatat limbah B3 medis meningkat dari 283,87 ton/hari menjadi 382,03 ton/hari saat pandemi [12].

\section{Rekomendasi Pengelolaan Sampah Saat Pandemi Covid-19}

Berdasarkan hasil penelitian yang dilakukan terhadap jumlah sampah di TPA Regional Kota Payakumbuh sebelum dan saat pandemi berlangsung menunjukkan adanya penurunan jumlah sampah yang masuk selama pandemi Covid-19. Hal ini dipengaruhi adanya pembatasan aktivitas masyarakat di luar rumah, terutama saat diberlakukan PSBB. Pembatasan ini dimaksudkan untuk mencegah dan mengurangi penularan wabah Covid-19.

Sumber sampah yang berdampak terutama pada sumber institusi meliputi perkantoran dan pendidikan. Timbulan sampah pada sumber ini menurun drastis karena banyak perkantoran dan pendidikan yang tutup. Akibatnya kegiatan pada kedua sumber dilakukan di rumah dengan penerapan WFH dan SFH. Hal ini berdampak terhadap timbulan sampah dari sumber domestik. Timbulan sampah dari sumber domestik mengalami kenaikan, yang dalam penelitian ini kenaikannya lebih dari 20\%. Komposisi sampah sebelum dan saat pandemi Covid-19 masih didominasi oleh sampah makanan, sampah plastik dan sampah kertas. Komposisi ketiga sampah ini cenderung meningkat dibandingkan sebelum pandemi [15].

Rekomendasi yang dapat diberikan terkait pengelolaan sampah saat pandemi diuraikan sebagai berikut:

Untuk masyarakat:

1. Melakukan pemilahan sampah dengan penyediaan dan penerapan wadah terpilah. Berdasarkan Peraturan Menteri Pekerjaan Umum no. 03 Tahun 2013 tentang Penyelenggaraan Prasarana dan Sarana Persampahan dalam Penanganan Sampah Rumah Tangga dan Sejenis Sampah Rumah Tangga, pemilahan dilakukan terhadap 5 jenis sampah, yaitu sampah layak kompos, sampah guna ulang, sampah daur ulang, sampah B3 dan sampah residu (lain-lain) [17].

2. Melakukan pengomposan untuk sampah layak kompos. Pengomposan dapat dilakukan dengan berbagai teknologi untuk skala rumah tangga seperti metode Takakura, pengomposan Lubang Resapan Biopori (LRB) dan pengomposan Vermi.

3. Melakukan guna ulang dan daur ulang terhadap sampah plastik dan sampah kertas.

4. Melakukan reduksi sampah mulai dari sumber dengan kegiatan menggunakan produk yang dapat diisi ulang (refill) seperti botol minum pribadi yang bisa diisi ulang, menggunakan wadah atau kantong sendiri seperti tote bag saat berbelanja, dan menghindari pemakaian produk sekali pakai yang menghasilkan sampah, seperti penggunaan sedotan plastik yang dapat diganti menjadi sedotan stainless.

5. Melakukan penanganan khusus untuk sampah medis yang dihasilkan dari rumah tangga dengan cara pemilahan, pewadahan dan desinfeksi, serta pelabelan.

Untuk pemerintah:

1. Memberikan sosialisasi dan pendampingan tentang pengelolaan sampah dengan konsep 3R (Reduce, Reuse, dan Recycle).

2. Memberikan sosialisasi dan pelatihan tentang tentang metode pengomposan dan daur ulang sampah.

3. Memberikan sosialisasi tentang pengelolaan sampah medis terutama yang berhubungan dengan limbah Covid-19.

4. Bekerjasama dengan sektor informal sebagai mitra bank sampah dalam daur ulang sampah. Sektor informal merupakan sektor ekonomi yang terdiri dari unit-unit usaha berskala kecil yang melakukan pengelolaan sampah seperti pemulung, lapak/pengepul, bandar dan industri daur ulang sampah. 


\section{Kesimpulan}

Dari hasil perbandingan jumlah sampah masuk ke TPA Regional Kota Payakumbuh didapatkan penurunan sampah sebesar $11,15 \%$ saat pandemi berlangsung. Jumlah sampah masuk sebelum pandemi sebesar 237,359 ton/hari, sedangkan saat pandemi berlangsung sampah menurun menjadi 210,896 ton/hari. Sumber sampah yang paling terpengaruh saat pandemi Covid-19 adalah sumber institusi dengan penurunan sampah sebesar 50\%. Penurunan sampah juga terjadi pada sumber sampah fasilitas layanan kota sebesar $37,23 \%$ dan sumber sampah komersil sebesar 29,48\%. Sebaliknya, pada sumber domestik terjadi kenaikan jumlah sampah saat pandemi Covid-19 sebesar 21,22\%. Rekomendasi yang diberikan untuk pengelolaan sampah saat pandemi Covid-19 berlangsung untuk masyarakat adalah melakukan pemilahan sampah, melakukan pengomposan sampah mudah terurai, melakukan guna ulang dan daur ulang sampah kertas dan sampah plastik, melakukan reduksi sampah, dan melakukan penanganan untuk sampah medis yang dihasilkan di rumah tangga, serta peran pemerintah untuk memberikan edukasi kepada masyarakat serta kerjasama dengan sektor informal.

\section{Singkatan}

$S B$

$S A$
Sebelum Pandemi

Saat Pandemi

\section{Referensi}

[1] N. Mona, "Konsep isolasi dalam jaringan sosial untuk meminimalisasi efek contagius (kasus penyebaran virus corona di Indonesia)," J. Sosial Humaniora Terapan, vol. 2 (2), hal. 118-125, 2020.

[2] Undang Undang Republik Indonesia Nomor 6 tahun 2018 tentang Kekarantinaan Kesehatan, Jakarta: Sekretariat Negara, 2018.

[3] Peraturan Gubernur Sumbar Nomor 20 Tahun 2020 tentang Pedoman Pembatasan Sosial Berskala Besar dalam Penangan Corona Virus Diseases (Covid-19), Padang, 2020.

[4] Anonim, "Selama pandemi covid-19, volume sampah di Jakarta Timur Turun hingga 300 ton per hari", $26 \quad$ April 2020, [online]. https://megapolitan.kompas.com/read/2020/04/26/08181381/selama-pandemi-Covid-19-volumesampah-di-jakarta-timur-turun-hingga-300 [Diakses 29 Maret 2021].

[5] O. Oktorie, "Studi dampak sampah terhadap kondisi fisik dan kimia lingkungan sebelum dan saat wabah Covid-19 di Kota Padang, Sumatera Barat, Indonesia," Padang: Universitas Negeri Padang, 2020.

[6] F. Anggraini, "Pengembangan Standar Nasional Indonesia (SNI) 03-3241-1994 untuk Standarisasi Pemilihan Lokasi Tempat Pemrosesan Akhir Sampah (TPAS) Regional".. Tersedia: http://download.garuda.ristekdikti.go.id/article.php?article=954232\&val=14695\&title=PEMILIHAN\% 2 0LOKASI\%20TPA\%20SAMPAH\%20REGIONAL\%20SEBAGAI\%20BAHAN\%20REVISI\%20SNI\% 2003-3241-1994 [Diakses 18 Juli 2020]

[7] S. Raharjo, A. Pratoto, A. Hazmi, Sirdany, T. Ihsan, dan A. Khaira, "Analisis konsentrasi gas metan $\left(\mathrm{CH}_{4}\right)$ dari di tempat pemrosesan akhir (TPA) sampah regional payakumbuh sebagai sumber energi alternatif, " Prosiding: Seminar Nasional Sains dan Teknologi Lingkungan I (SNSTL I), Padang, January 2014. [Indonesian].

[8] SNI 19-3964-1994. Metode Pengambilan dan Pengukuran Contoh Timbulan dan Komposisi Sampah Perkotaan. Departemen Pekerjaan Umum: Bandung, 1994.

[9] R. T. Hardi dan R. Akbar, "Pengaruh pandemi covid-19 terhadap karakteristik sampah padat pada kawasan Summarecon Serpong," J. Teknologi dan Desain (JTD), vol. 2 (2), hal. 94-103, 2021.

[10] M. L. Lukman, Volume sampah Kota Bandung turun selama PSBB. [onlie]. Tersedia: https://galamedia.pikiran-rakyat.com/news/pr-35563087/volume-sampah-di-kota-bandung-turunselama-psbb [Diakses 18 Juli 2020].

[11] Tim Portal Jember, "Dampak positif WFH covid-19, terjadi penurunan sampah 500 ton di cianjur," 16 April 2020, [online]. Tersedia: https://portaljember.pikiran-rakyat.com/regional/pr16366758/dampak-positif-wfh-Covid-19-terjadi-penurunan-sampah-500-ton-di-cianjur [Diakses 17 Juli 2020].

[12] Anonim, "Virus Corona limbah infeksius covid-19 masih ditemukan di TPA, ada kelonggaran, pengabaian, dan tidak ada pengawasan," 24 Oktober 2020, [online]. Tersedia: https://www.bbc.com/indonesia/majalah-54640725_[Diakses 29 Maret 2021]. 
[13] O. Ouhsine, A. Ouigmane, E. Layati, B. Aba, R. J. Isaifan, dan M. Berkani, "Impact of Covid-19 on the qualitative and quantitative aspect of household solid waste," Global J. of Environmental Science and Management, vol. 6 (4), pp. 1-12, 2020.

[14] A. Ouigmane, O. Boudouch. A. Hasib, O, Ouhsine, E. Lajati, R. J. Isaifan, E. Alaatchane, A. Mottassadik, and M. Berkani, "Effect of COVID-19 on the Generation of Waste in Marrakech, Morocco," J. of Health and Pollution, vol. 11 (30), 2021.

[15] Y. Ruslinda, R. Aziz, dan F. F. Putri, "Analysis of household solid waste generation and composition during the covid-19 pandemic in Padang City, Indonesia," Indonesian J. of Environmental Management and Sustainability, vol. 4 (4), pp 116-124, 2020.

[16] Nurdin, "Dampak pandemi Covid-19 terhadap peningkatan sampah plastik," 11 Juli 2020, [online]. Tersedia: http://oseanografi.lipi.go.id/news/show/202 [Diakses 18 Juli 2020].

[17] Menteri Pekerjaan Umum Republik Indonesia, Peraturan No. 3 tentang Penyelenggaraan Prasarana dan Sarana Persampajan dalam Penanganan Sampah Rumah Tangga dan Sampah Sejenis sampah Rumah Tangga, 2013. 